\title{
THE EFFECT OF THE COVID-19 PANDEMIC ON FORENSIC CASES OF EMERGENCY MEDICAL SERVICES
}

\section{COVID-19 PANDEMİSINİN HASTANE ÖNCESİ ACİL SAĞLIK HİZMETLERİNDEKİ ADLİ VAKALARA ETKİSI}

Burak BEKGOZ ${ }^{1}$, İshak SAN ${ }^{2}$

\begin{abstract}
AIM: The aim of this study is to evaluate the effects of the COVID-19 pandemic on forensic cases treated by Emergency Medical Services compared to the pre-pandemic periods.

MATERIAL AND METHOD: The study was designed to evaluate the Emergency Medical Services cases retrospectively. We included forensic cases data covering pandemic period (period A - from March 11, 2020 to March 10, 2021) and pre-pandemic period (period B - from March 11 and period C - 2019 to March 10, 2020) in Ankara, Turkey.

RESULTS: We included a total of 117,753 patients. The most common type of forensic case in all periods was traffic accidents $(62.9 \%)$. This was followed by assaults $(14.1 \%)$ and suicides $(8.2 \%)$. The number of traffic accidents was found to be lower during the pandemic period $(60.3 \%)$ than in other periods $(p<0.001)$. In addition, suicides (9.2\%), injuries with sharp/blunt objects $(7.5 \%)$ were also higher in the pandemic period compared to the prepandemic periods $(\mathrm{p}<0.001)$. Most of the cases had yellow triage code $(48.6 \%)$. Considering the triage codes, during the pandemic period, the green-coded cases decreased and black-coded cases increased compared to pre-pandemic.
\end{abstract}

CONCLUSION: The number of forensic cases in the COVID-19 pandemic was significantly lower than in the pre-pandemic periods. In addition, suicide cases and sharp/blunt object injuries were more frequent in the pandemic period than in the pre-pandemic periods. Traffic accidents were still the most frequent despite the lockdowns during the pandemic period.

Keywords: COVID-19, Suicide, Emergency Medical Services

\section{ÖZET}

AMAÇ: Bu çalışmanın amacı, COVID-19 pandemisinin, pandemi öncesi döneme göre Hastane Öncesi Acil Sağllk Hizmetleri ile müdahale edilen adli vakalardaki etkisini araştırmaktır.

GEREÇ VE YÖNTEM: Çalışma Hastane Öncesi Acil Sağlık Hizmetlerinde retrospektif olarak planlandı. Çalışmamıza Ankaradaki pandemi dönemi (Periyot A: 11 Mart 2020 - 10 Mart 2021) ve pandemi öncesi dönemi (Periyot B: 11 Mart 2019 - 10 Mart 2020 ve periyot C: 11 Mart - 11 Mart 2020) kapsayan adli vaka verilerini dahil ettik.

BULGULAR: Calıșmaya toplam 117.753 hastayı dahil edildi. Tüm dönemlerde en sık görülen adli vaka türü trafik kazalarıydı $(\% 62,9)$. Bunu darp $(\% 14,1)$ ve intiharlar $(\% 8,2)$ izliyordu. Pandemi döneminde trafik kazası sayısı $(\% 60,3)$ diğer dönemlere göre daha düşük bulundu $(\mathrm{p}<0,001)$. Ayrıca pandemi döneminde intiharlar $(\% 9,2)$, kesici/künt cisim yaralanmaları $(\% 7,5)$ pandemi öncesi döneme göre daha yüksekti $(\mathrm{p}<0,001)$. Olguların çoğunda sarı triyaj kodu vardı (\%48.6). Triyaj kodlarına bakıldığında pandemi döneminde pandemi öncesine göre yeşil kodlu vakalar azaldı, siyah kodlu vakalar artmıștı.

SONUÇ: COVID-19 pandemisindeki adli vaka sayısı, pandemi öncesi döneme göre önemli ölçüde düşüktü. Ayrıca pandemi döneminde intihar vakaları ve kesici/künt cisim yaralanmaları pandemi öncesi döneme göre daha sıktı. Pandemi döneminde sokağa çıkma kısıtlamalarına rağmen trafik kazaları en sık adli vaka nedeni olmaya devam etti.

Anahtar Kelimeler: COVID-19, İntihar, Acil Sağlık Hizmetleri

${ }^{1}$ Ankara City Hospital, Department of Emergency Medicine, Ankara, Turkey

${ }^{2}$ University of Health Sciences, Ankara City Hospital, Department of Emergency Medicine Ankara, Turkey

Gelis Tarihi / Submitted : Ekim 2021 / October 2021
Kabul Tarihi / Accepted : Aralık 2021 / December 2021

\author{
Sorumlu Yazar / Corresponding Author: \\ Burak BEKGOZ \\ Bağlıca Neigh., Karatuz Street1366. Elit Bağ Sitesi A/6, Etimesgut, Ankara, Turkey \\ Gsm: +905056643952 \\ E-mail: drburakbekgoz@gmail.com
}

Yazar Bilgileri / Author Information:

Burak BEKGOZ (ORCID: 0000-0002-4183-9633),

İshak SAN (ORCID: 0000-0002-9658-9010) 


\section{INTRODUCTION}

It is called a "forensic case" when a person intentionally or carelessly causes another person's death or deterioration of physical or mental health $(1,2)$. Injuries with gunshots, explosives or sharp objects, traffic accidents, falls, assaults, occupational accidents, poisonings, burns, drownings, suicides, all deaths suspected to be caused by murder, and sexual assaults are examples of urgent forensic cases. (3). Most of the forensic cases are also urgent cases and concern both ambulance services and emergency rooms (4).

The COVID-19 disease, which first emerged as viral pneumonia cases unknown etiology in Wuhan, China at the end of 19, has become a pandemic that has affected the whole world over time $(5,6)$. As the disease became a worldwide pandemic in a short time, governments had to take some measures such as lockdown, partial or complete closure of schools and businesses, quarantine in certain geographical areas and restrictions on international travel (7). After the intense COVID-19 pandemic patient density and the measures taken, the behavior patterns of the patients also changed, and the EMS patient profile also changed during the pandemic period (8).

Venter et al. reported that the cases of violence and traffic accidents decreased by $25 \%$ during the pandemic period compared to the pre-pandemic periods (9), while another study found that the COVID-19 pandemic increased the risk of suicides (10). Studies evaluating the effect of the COVID-19 pandemic on forensic cases in the literature generally evaluated patients who applied to the emergency rooms. Although most of these patients are first treated by emergency medical services (EMS), there are no studies evaluating the effects of the COVID-19 pandemic on forensic cases treated by EMS.

The aim of this study is to evaluate the effects of the COVID-19 pandemic on forensic cases treated by EMS compared to the pre-pandemic periods.

\section{MATERIAL AND METHOD}

The study was designed to evaluate the Ankara EMS cases retrospectively. The first COVID-19 case in Turkey was diagnosed in March 11, 2020. In our study, we included forensic cases data covering pandemic period (period A - from March 11, 2020 to March $10,2021)$ and pre-pandemic period (period B - from March 11 and period C - 2019 to March 10, 2020) in Ankara, Turkey. We included a total of 117,753 patients, 30,893 during the pandemic period, 43,053 from the 1-year period before the pandemic, and 43,807 from the period 2 years before the pandemic. This study was approved by the Non-Invasive Ethics Committee of the Dr. Abdurrahman Yurtaslan Ankara Oncology Training and Research Hospital (Number: 2021-05/1175).
All EMS cases in Turkey are recorded in the database named ASOS belonging to the Turkish Ministry of Health. We obtained the data of the study from this database. We used the International Classification of Diseases-10 (ICD-10) for our study. According to these codes, we considered traffic accidents, assaults, intentional self-harms, sharp/blunt object injuries, falls, poisonings, burns, suspicious deaths, and gunshot injuries as forensic cases. We included the data of patients with these diagnoses in our study. We also included the demographic characteristics of the patients, whether the patients were transferred to the hospital, case days and triage codes.

\section{Statistical Analysis}

All data were analyzed using IBM SPSS for Windows version 25.0 (Armonk, NY: IBM Corp.) In addition to descriptive statistics (frequency, percentage, mean, standard deviation), Chi-Square ( $\chi 2)$ test was used to compare qualitative data. Bonferroni adjustment was applied to find the cause of the difference when there was a difference. The compliance of the data to normal distribution was evaluated by Kolmogorov-Smirnov test, Skewness-Kurtosis, and graphical methods (histogram, Q-Q Plot, Stem and Leaf, Boxplot). In the study, the Independent Samples t-test and the OneWay ANOVA test (one-way analysis of variance) were used to evaluate quantitative data compatible with normal distribution. When there was difference in multiple comparisons, the post-hoc Tukey HSD test was used to find the cause of difference. Statistical significance was accepted as $\alpha=0,05$.

\section{RESULTS}

We included a total of 117,753 patients, 30,893 during the pandemic period (March 11,2020-March 10,2021), 43,053 from the 1 -year period before the pandemic (March 11 2019- March 10, 2020), and 43,807 from the period 2 years before the pandemic (March 11, 2018, March 10, 2019). During the pandemic period, the number of forensic cases was lower than in other periods $(\mathrm{p}<0.001)$. Of the patients, 79,436 $(67.4 \%)$ were men. The mean age of the patients included in the study was found to be $33,7 \pm 16,9$ years (Table 1 ).

The most common type of forensic case in all periods was traffic accidents (62.9\%). This was followed by assaults (14.1\%) and suicides (8.2\%). The number of traffic accidents was found to be lower during the pandemic period $(60.3 \%)$ than in other periods $(p<0.001)$. In addition, suicides $(9.2 \%)$, injuries with sharp/blunt objects $(7.5 \%)$ were also higher in the pandemic period compared to the pre-pandemic periods $(\mathrm{p}<0.001)$. The least number of assault cases was 2 years before the pandemic period (13.7\%) (Table 2).

Most of the cases had yellow triage code (48.6\%). Considering the triage codes, during the pandemic period, the green-coded cases decreased and black- 
Table 1. Forensic Cases by Gender and Year

\begin{tabular}{|c|c|c|c|c|c|c|}
\hline & Period $A^{*}$ & Period B $^{\star *}$ & Period $C^{\star * *}$ & Total & $\mathbf{P}$ & Difference \\
\hline Men (n / \%) & $21,767(70.5 \%)$ & $\begin{array}{l}28,486- \\
(66.2 \%)\end{array}$ & $\begin{array}{l}29,183- \\
(66.6 \%)\end{array}$ & $\begin{array}{c}79,436 \\
(67.5 \%)\end{array}$ & $<0.001^{a}$ & $\begin{array}{c}\text { Between A and } \\
\text { B-C }\end{array}$ \\
\hline Age (Years)* & $33.7 \pm 15.6$ & $33.3 \pm 16.7$ & $33.6 \pm 16.7$ & $33.5 \pm 16.4$ & $0.018^{b}$ & Between A and B \\
\hline Women (n / \%) & $9,126(29,5 \%)$ & $\begin{array}{c}14,567 \\
(33,8 \%)\end{array}$ & $\begin{array}{c}14,624 \\
(33,4 \%)\end{array}$ & $\begin{array}{c}38,317 \\
(32,5 \%)\end{array}$ & $<0.001^{a}$ & $\begin{array}{c}\text { Between A and } \\
\text { B-C }\end{array}$ \\
\hline Age $(\text { Years })^{*}$ & $34.3 \pm 17.1$ & $34.3 \pm 18.3$ & $34.0 \pm 18.2$ & $34.2 \pm 18.0$ & $0.324^{\mathrm{b}}$ & -- \\
\hline Total (n / \%) & $30,893(26.2 \%)$ & $\begin{array}{c}43,053 \\
(36.6 \%)\end{array}$ & $\begin{array}{c}43,807 \\
(37.2 \%)\end{array}$ & $\begin{array}{c}117,753 \\
(100.0 \%)\end{array}$ & $<0.001^{a}$ & $\begin{array}{c}\text { Between A and } \\
\text { B-C }\end{array}$ \\
\hline Age $(\text { Years })^{*}$ & $33.9 \pm 16.1$ & $33.6 \pm 17.3$ & $33.7 \pm 17.2$ & $33.7 \pm 16.9$ & $0.138^{b}$ & -- \\
\hline $\mathbf{P}^{c}$ & 0.006 & $<0.001$ & $<0.001$ & $<0.001$ & & \\
\hline
\end{tabular}

${ }^{*}$ from March 11, 2020 to March 10, 2021, ${ }^{* *}$ from March 11, 2019 to March 10, 2020, ${ }^{* * *}$ from March 11, 2018 to March 10, 2019

* Mean $\pm \mathrm{SD}$, ${ }^{\# *}$ Percentage in row

a: Chi-Square Test (Post-hoc: Bonferroni), b: One-Way Anova Test (Post-Hoc: Tukey), c: Independent Samples t Test

Table 2. Comparison of patients by diagnosis and periods

\begin{tabular}{|c|c|c|c|c|c|c|}
\hline $\begin{array}{l}\text { Diagnostic } \\
\text { Groups }\end{array}$ & Period $A^{\star}$ & $\underset{B^{\star *}}{\text { Period }}$ & Period $C^{\star * *}$ & Total & $\mathbf{P}^{\#}$ & Difference \\
\hline Traffic accidents & $\begin{array}{c}18,637 \\
(60.3 \%)\end{array}$ & $\begin{array}{c}27,045 \\
(62.8 \%)\end{array}$ & $\begin{array}{c}28,375 \\
(64.8 \%)\end{array}$ & $74,057(62.9 \%)$ & \multirow{9}{*}{$<0.001$} & A-B-C \\
\hline Assaults & $\begin{array}{l}4.445,0 \\
(14.4 \%)\end{array}$ & $\begin{array}{c}6.195,0 \\
(14.4 \%)\end{array}$ & $\begin{array}{l}5.995,0 \\
(13.7 \%)\end{array}$ & $16.635,0(14.1 \%)$ & & Between C and A- B \\
\hline $\begin{array}{l}\text { Intentional Self- } \\
\text { Harm }\end{array}$ & $\begin{array}{c}2,844 \\
(9.2 \%)\end{array}$ & $\begin{array}{c}3,362 \\
(7.8 \%)\end{array}$ & $\begin{array}{c}3,410 \\
(7.8 \%)\end{array}$ & $9,616(8.2 \%)$ & & Between A and B-C \\
\hline $\begin{array}{l}\text { Sharp/blunt } \\
\text { object injuries }\end{array}$ & $\begin{array}{c}2,332 \\
(7.5 \%)\end{array}$ & $\begin{array}{l}2,727 \\
(6.3 \%)\end{array}$ & $\begin{array}{l}2,569 \\
(5.9 \%)\end{array}$ & $7,628(6.5 \%)$ & & Between A-B-C \\
\hline Falls & $\begin{array}{l}1,071 \\
(3.5 \%)\end{array}$ & $\begin{array}{c}1,423 \\
(3.3 \%)\end{array}$ & $\begin{array}{l}1,554 \\
(3.5 \%)\end{array}$ & $4,048(3.4 \%)$ & & -- \\
\hline Poisonings & $\begin{array}{l}485 \\
1.6\end{array}$ & $\begin{array}{l}902 \\
2.1\end{array}$ & $\begin{array}{c}570 \\
(\% 1.3)\end{array}$ & $1,957(1.7 \%)$ & & Between A-B-C \\
\hline Burns & $\begin{array}{c}362 \\
(1.2 \%)\end{array}$ & $\begin{array}{c}669 \\
(1.6 \%)\end{array}$ & $\begin{array}{c}555 \\
(1.3 \%)\end{array}$ & $1,586(1.3 \%)$ & & Between B and A- C \\
\hline Firearm Injuries & $\begin{array}{c}359 \\
(1.2 \%)\end{array}$ & $\begin{array}{c}325 \\
(0.8 \%)\end{array}$ & $\begin{array}{c}445 \\
(1.0 \%)\end{array}$ & $1,129(1.0 \%)$ & & Between B and A- C \\
\hline Others & $\begin{array}{c}358 \\
(1.2 \%)\end{array}$ & $\begin{array}{c}405 \\
(0.9 \%)\end{array}$ & $\begin{array}{c}334 \\
(0.8 \%)\end{array}$ & $1,097(0.9 \%)$ & & Between A-B-C \\
\hline Total & $\begin{array}{c}30,893 \\
(100.0 \%)\end{array}$ & $\begin{array}{c}43,053 \\
(100.0 \%)\end{array}$ & $\begin{array}{c}43,807 \\
(100.0 \%)\end{array}$ & $\begin{array}{c}117,753 \\
(100.0 \%)\end{array}$ & & \\
\hline
\end{tabular}

*from March 11, 2020 to March 10, 2021, ${ }^{* *}$ from March 11, 2019 to March 10, 2020, ${ }^{* * *}$ from March 11, 2018 to March 10, 2019

"Chi-Square Test (Post-hoc: Bonferroni)

coded cases increased compared to pre-pandemic. No statistically significant difference was found between pandemic and pre-pandemic periods in yellow-coded cases (Table 3). Black-coded patients who died at the scene were mostly suicide cases. It was found that suicide cases were more frequent than other periods during the pandemic period $(\mathrm{p}<0.001)$.

In our study, cases were most frequent on Wednesdays (15.1\%) and Mondays (15.0\%) during the pandemic period. There was no significant difference between the pandemic and pre-pandemic periods in the number of cases on Mondays. There was a significant difference between the pandemic and pre-pandemic periods in the number of cases on Wednesdays $(p<0.001)$. Saturdays and Sundays were the most frequent days with forensic cases during the pre-pandemic periods. In both of these days, a significant difference was found in the number of cases between pandemic and pre-pandemic periods $(\mathrm{p}<0.001) \quad($ Table 4). Cases were most frequent in July (12.5\%) and June (10.7\%) during the pandemic period. The number of the cases was most frequent in August (9.7\%) and June (9.6\%) one year before the pandemic period, while it was in July (10.6\%) and June (9.9\%) two years before the pandemic (Figure). 
Table 3. Triage codes of the cases

\begin{tabular}{|c|c|c|c|c|c|c|}
\hline $\begin{array}{l}\text { Triage } \\
\text { code }\end{array}$ & Period A* & Period B ${ }^{\star *}$ & Period $C^{\star * *}$ & Total & $\mathbf{P}^{\#}$ & Difference \\
\hline Green & $\begin{array}{l}12,005 \\
(38.9 \%)\end{array}$ & $\begin{array}{c}17,189 \\
(39.9 \%)\end{array}$ & $\begin{array}{l}18,424 \\
(42.1 \%)\end{array}$ & $\begin{array}{c}47,618 \\
(40,4 \%)\end{array}$ & \multirow{5}{*}{$<0.001$} & Between A-B-C \\
\hline Yellow & $\begin{array}{c}15,369 \\
(49.7 \%)\end{array}$ & $\begin{array}{c}21,176 \\
(49.2 \%)\end{array}$ & $\begin{array}{c}20,645 \\
(47.1 \%)\end{array}$ & $\begin{array}{c}57,190 \\
(48.6 \%)\end{array}$ & & Between C and A- B \\
\hline Red & $\begin{array}{c}2,719 \\
(8.8 \%)\end{array}$ & $\begin{array}{c}3,821 \\
(8.9 \%)\end{array}$ & $\begin{array}{l}3,820 \\
(8.7 \%\end{array}$ & $\begin{array}{l}10,360 \\
(8.8 \%)\end{array}$ & & -- \\
\hline Black & $\begin{array}{c}800 \\
(2.6 \%)\end{array}$ & $\begin{array}{c}867 \\
(2.0 \%)\end{array}$ & $\begin{array}{c}918 \\
(2.1 \%)\end{array}$ & $\begin{array}{c}2,585 \\
(2.2 \%)\end{array}$ & & Between A and B-C \\
\hline Total & $\begin{array}{c}30,893 \\
(100.0 \%)\end{array}$ & $43,053(100.0 \%)$ & $\begin{array}{c}43,807 \\
(100.0 \%)\end{array}$ & $\begin{array}{c}117,753 \\
(100.0 \%)\end{array}$ & & \\
\hline
\end{tabular}

${ }^{*}$ from March 11, 2020 to March 10, 2021, ${ }^{* *}$ from March 11, 2019 to March 10, 2020, ${ }^{* * *}$ from March 11, 2018 to March 10, 2019

"Chi-Square Test (Post-hoc: Bonferroni)

Table 4. Number of forensic cases by day

\begin{tabular}{|c|c|c|c|c|c|c|}
\hline & Period $A^{*}$ & Period B ${ }^{\star *}$ & Period $C^{* * *}$ & Total & $\mathbf{P}^{\#}$ & Difference \\
\hline Monday & $\begin{array}{c}4,631 \\
(15.0 \%)\end{array}$ & $\begin{array}{c}6,251 \\
(14.5 \%)\end{array}$ & $\begin{array}{c}6,001 \\
(13.7 \%)\end{array}$ & $\begin{array}{c}16,883 \\
(14.3 \%)\end{array}$ & \multirow{7}{*}{$<0.001$} & Between $\mathrm{C}$ and $\mathrm{A}-\mathrm{B}$ \\
\hline Tuesday & $\begin{array}{c}4,396 \\
(14.2 \%)\end{array}$ & $\begin{array}{c}5,940 \\
(13.8 \%)\end{array}$ & $\begin{array}{c}6,155 \\
(14.1 \%)\end{array}$ & $\begin{array}{c}16,491 \\
(14.0 \%)\end{array}$ & & -- \\
\hline Wednesday & $\begin{array}{c}4,653 \\
(15.1 \%)\end{array}$ & $\begin{array}{c}5,811 \\
(135 \%)\end{array}$ & $\begin{array}{c}5,740 \\
(13.1 \%)\end{array}$ & $\begin{array}{c}16,204 \\
(13.8 \%)\end{array}$ & & Between A and B-C \\
\hline Thursday & $\begin{array}{c}4,494 \\
(14.5 \%)\end{array}$ & $\begin{array}{c}5,976 \\
(13.9 \%)\end{array}$ & $\begin{array}{c}6,043 \\
(13.8 \%)\end{array}$ & $\begin{array}{c}16,513 \\
(14.0 \%)\end{array}$ & & Between A and B-C \\
\hline Friday & $\begin{array}{c}4,574 \\
(14.8 \%)\end{array}$ & $\begin{array}{c}6,234 \\
(14.5 \%)\end{array}$ & $\begin{array}{c}6,241 \\
(14.2 \%)\end{array}$ & $\begin{array}{c}17,049 \\
(14.5 \%)\end{array}$ & & -- \\
\hline Saturday & $\begin{array}{c}4,063 \\
(13.2 \%)\end{array}$ & $\begin{array}{c}6,535 \\
(15.2 \%)\end{array}$ & $\begin{array}{c}6,713 \\
(15.3 \%)\end{array}$ & $\begin{array}{c}17,311 \\
(14.7 \%)\end{array}$ & & Between A and B-C \\
\hline Sunday & $\begin{array}{c}4,082 \\
(13.2 \%)\end{array}$ & $\begin{array}{c}6,306 \\
(14.6 \%)\end{array}$ & $\begin{array}{c}6,914 \\
(15.8 \%)\end{array}$ & $\begin{array}{c}17,302 \\
(14.7 \%)\end{array}$ & & Between A-B-C \\
\hline Total & $\begin{array}{c}30,893 \\
(100.0 \%)\end{array}$ & $\begin{array}{c}43,053 \\
(100.0 \%)\end{array}$ & $\begin{array}{c}43,807 \\
(100.0 \%)\end{array}$ & $\begin{array}{c}117,753 \\
(100.0 \%)\end{array}$ & & \\
\hline
\end{tabular}

*from March 11, 2020 to March 10, 2021, ${ }^{* *}$ from March 11, 2019 to March 10, 2020, ${ }^{* * *}$ from March 11, 2018 to March 10, 2019

"Chi-Square Test (Post-hoc: Bonferroni)

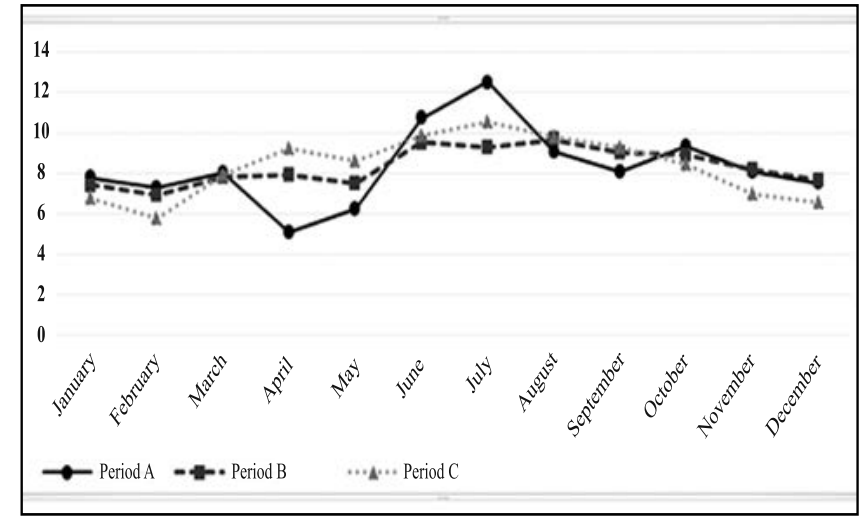

Figure 1: Forensic cases by months

\section{DISCUSSION}

We found that, in the pandemic period, compared to the pre-pandemic periods, the number of forensic cases was lower, traffic accidents were still the most frequent cases despite lockdown, and suicide cases and sharp/blunt object injuries were higher.

In a study by Kamine et al. evaluating traumas in the COVID-19 pandemic, it was found that motor vehicle accidents decreased significantly (57.4\% decrease, $\mathrm{p}<0.001$ ) (11). Another study conducted in France found that motor vehicle accidents decreased during the pandemic period compared to the pre-pandemic periods (12). In our study, similar to the literature, we found significant decreases in traffic accidents during the pandemic period compared to the pre-pandemic periods $(\mathrm{p}<0.001)$. We suggest that the lockdown was effective in significant decrease of traffic accidents frequencies during the pandemic period. In addition, the transition to online education, the practice of working from home in the public and private sectors, 
and the restriction of people's social lives due to fears of COVID-19 disease may have also been effective in reducing the number of traffic accidents.

In our study, we found that suicide cases increased significantly during the pandemic period (9.2\%) compared to the pre-pandemic periods $(7.8 \%)(\mathrm{p}<0.001)$. In a study evaluating suicides during the pandemic period in Japan, it was found that the number of suicides increased significantly in 2020 (13). In another study evaluating suicide cases during the COVID-19 period, it was found that the number of suicides increased during the pandemic period compared to previous years (14). In a review evaluating mental health problems in the COVID-19 pandemic, it was concluded that the COVID-19 pandemic also triggered the psychiatric epidemic (15). During the COVID-19 pandemic, people's mental health may have deteriorated, and this may have increased suicides, as people remained closed at home because of lockdown, and working from home, and socializing areas such as restaurants and cafes were closed.

In our study, we found that sharp/blunt object injuries also increased compared to the pre-pandemic periods. In a study by Olding et al., penetrating injuries were found to be significantly higher than in the pre-pandemic periods (16). We suggest that the reason for the increase in injuries with sharp/blunt objects during the pandemic period is due to the fact that people's psychology is broken due to lifestyle changes during the pandemic period.

In our study, the number of green triage coded cases decreased significantly during the pandemic period compared to the pre-pandemic periods. In addition, the number of black triage coded cases were significantly higher in the pandemic period. A study in South Africa found that gunshot injuries increased by $80 \%$ after the lockdown application during the pandemic period (17). In a study by Sakamoto et al., it was found that deaths due to suicides increased during the pandemic period in Japan (14). The finding of our study that mortality rates are higher in the pandemic period than in other periods is consistent with the literature. We suggest that during the pandemic, people's being alone at home and the restriction of their social lives are the reasons for this.

In a pre-pandemic study by Türkçüer et al., it was found that the most forensic case applications to the emergency rooms were on Mondays (the most frequent) and Saturdays (2nd most frequent). In the same study, on a seasonal basis, the highest number of applications was found to be in June, July, and August (18). In our study, we found that the most frequent days during the pandemic period were Mondays and Wednesdays, while, in the pre-pandemic periods, it was Saturdays and Sundays. We found that the reason why forensic cases were more frequent on weekdays rather than on weekends during the pandemic period is that a lockdown was applied at weekends in Turkey. Similar to the literature, we found that forensic cases were most frequent in June, July, and
August, both before and during the pandemic.

\section{Limitations}

In our study, we could not determine whether the sharp/ blunt object injuries were due to assaults or other reasons since detailed information was not available in the database. In addition, we could not determine whether the poisonings were caused by suicide or any other reason. Therefore, the number of forensic cases caused by assaults or suicides may be higher. More detailed analysis of subgroups in new studies may provide clearer information about the details of forensic cases.

\section{CONCLUSION}

We found that the number of forensic cases in the COVID-19 pandemic was significantly lower than in the pre-pandemic periods. We have found that traffic accidents were still the most frequent despite the lockdowns during the pandemic period. In addition, suicide cases and sharp/blunt object injuries were more frequent in the pandemic period than in the pre-pandemic periods. The number of patients found dead at the scene (black code triage) during the pandemic period was higher than the pre-pandemic periods.

\section{Authors' Contributions}

Burak Bekgöz conceived the study and designed the trial. İshak Şan gathered and analyzed the data. İshak Şan and Burak Bekgöz drafted the manuscript and all authors contributed substantially to its revision.

\section{REFERENCES}

1.)Türkmen N, Akgöz S, Çoltu A, ve ark. Uludağ Üniversitesi Tıp Fakültesi Acil Servisine Başvuran Adli Olguların Değerlendirilmesi. Uludağ Üniversitesi Tip Fakültesi Derg. 2005;31:25-9.

2.)Karadayı B, Kolusayın MÖ, Kaya A, ve ark. Collection and transfer of biological materials from forensic cases in emergency units [Article in Turkish] Marmara Med J. 2013;26:111-7

3.)Ilçe A, Yıldız D, Baysal G, ve ark. Acil servislerde çalıșan sağlık bakım personelinin adli olgularda delillerin korunması ve saklanmasına yönelik bilgi ve uygulamalarının incelenmesi [Analysis of the knowledge and practices of health care workers in Emergency Departments regarding the protection and preservation of evidence in forensic cases]. Ulus Travma Acil Cerrahi Derg. 2010;16:546-51. 4.)Asci O, Hazar G, Sercan I. The approach of prehospital health care personnel working at emergency stations towards forensic cases. Turk J Emerg Med. 2015;15:131-5.

5.)World Health Organization. Novel Coronavirus (2019-nCoV) - Situation report - 1, 21 Jan 2020. Available at: https://www.who. int/docs/default-source/coronaviruse/situation-reports/20200121sitrep-1-2019-ncov.pdf?sfvrsn=20a99c10_4. (Accessed 16.10.2021). 6.)Backer JA, Klinkenberg D, Wallinga J. Incubation period of 2019 novel coronavirus (2019-nCoV) infections among travellers from Wuhan, China, 20-28 January 2020. Euro Surveill. 2020;25:2000062. 7.)Dey A, Majumdar P, Saha A, et al. COVID-19 pandemic lockdowninduced altered sleep/wake circadian rhythm, health complaints and stress among traffic police personnel in India. Chronobiol Int. 2021;38:140-8.

8.)Şan İ, Usul E, Bekgöz B, et al. Effects of COVID-19 Pandemic on Emergency Medical Services. Int J Clin Pract. 2021;75:e13885.

9.) Venter A, Lewis CM, Saffy P, et al. Locked down: Impact of COVID-19 restrictions on trauma presentations to the emergency department. S Afr Med J. 2020;111:52-6.

10.)Sher L. The impact of the COVID-19 pandemic on suicide 
rates. QJM. 2020;113:707-12.

11.)Kamine TH, Rembisz A, Barron RJ, et al. Decrease in Trauma Admissions with COVID-19 Pandemic. West J Emerg Med. 2020;21:819-22.

12.)Keays G, Friedman D, Gagnon I. Injuries in the time of COVID-19. Health Promot Chronic Dis Prev Can. 2020;40:336-41 13.)Nomura $S$, Kawashima $T$, Yoneoka $D$, et al. Trends in suicide in Japan by gender during the COVID-19 pandemic, up to September 2020. Psychiatry Res. 2021;295:113622.

14.)Sakamoto $H$, Ishikane $M$, Ghaznavi $C$, et al. Assessment of Suicide in Japan During the COVID-19 Pandemic vs Previous Years. JAMA Netw Open. 2021;4:e2037378.
15.)Hossain MM, Tasnim S, Sultana A, et al. Epidemiology of mental health problems in COVID-19: a review. F1000Res. 2020;23:636. 16.)Olding J, Zisman $S$, Olding $C$, et al. Penetrating trauma during a global pandemic: Changing patterns in interpersonal violence, selfharm and domestic violence in the Covid-19 outbreak. Surgeon. 2021;19:e9-13.

17.)Navsaria $\mathrm{PH}, \mathrm{Nicol} A J$, Parry $\mathrm{CDH}$, et al. The effect of lockdown on intentional and nonintentional injury during the COVID-19 pandemic in Cape Town, South Africa: A preliminary report. S Afr Med J. 2020;111:110-3.

18.)Türkçüer, İ, Gözlükaya, A, Serinken, $M$, et al. Adli olguların acil servise başvuru zamanları. Akademik Acil Tip Dergisi, 2010;2:89-92.

Ankara Eğt. Arş. Hast. Derg. (Med. J. Ankara Tr. Res. Hosp.), 2021 ; 54(3) : 465-470

Ethics Committee of the Dr. Abdurrahman Yurtaslan Ankara Oncology Training and Research Hospital (Number: 2021-05/1175). 